\title{
DIET IN TRAINING AND COMPETITIONS
}

by

John Ebbetts, M.R.C.S., L.R.C.P. (LONDON)

Paper presented at 1966 F. I. M.S. Congress in Hanover.

\section{$\underline{\text { SUMMARY }}$}

The principles underlying the formulation of a diet for young professionals undergoing training for, and taking part in, Competition Golf are dealt with. The composition of the diet and its supplementation are outlined. The literature on the subject is reviewed, and the absence of any really helpful work among so much which is contradictory is pointed out.

The reception of the diet over a three year period and its possible contribution to enhanced performance are discussed. The necessary components of such a diet are deduced in the light of experimental evidence and this experience. The importance of making the diet appetising and yet varying the calorie content to suit the underweight and the overweight individuals is stressed.

The advisability of two diets is indicated; one providing long term nourishment to support heavy training, and the other for use on competition days, when physical requirements demand rapid production of glucose and psychic inhibition prevents complicated digestion, absorption and oxidation.

\section{INTRODUCTION}

The paper presented now summarises the three years experience of the author in planning and providing a diet attractive, digestible and ergogenic for young British golf professionals undergoing training and participating in competition golf.

The students are from $18-25$ years of age and generally fit. They are selected by psychological aptitude tests and by physical assessment approximating in its results to Parnell's phenotype method (26). Candidates are chosen for potential resemblance to the 'golf physique' as represented by Nikolaus and others. Deficient muscular development is compensated, as far as possible, by the incorporation of specific 
exercises into their daily weight-training programme.

One hour daily, six days a week, is spent on weight training, two hours daily on cross country running and three hours on golf training for accuracy and distance. Four hours daily are spent on eating and drinking. Care is taken to individualise training and an attempt is made to promote and develop the psychological drives, which are necessary to outstanding performance in any sport, and which make possible the perseverance with meticulous and sometimes unavoidably irksome and monotonous training. The interest of the trainees is sustained, quite successfully in most cases, by the introduction of frequent changes of exercise regimes and by the preservation of a competitive element in the training.

Although training continues all the year round, it is continual only in the winter months, being broken up during the summer by an average of two days a week in competition play.

The trainees are under supervision for ten hours per day on six days per week, and during this time they have three daily main meals and two snacks, an arrangement which has proved in our hands as in those of several other authors $(14,17,32)$ more satisfactory than does a smaller number of meals. There is a good deal of self-selection in the menu during training, allowance being made for individual preferences and for individual dietary measures necessary to produce an optimum weight. A choice of dishes is presented at the main meals, each of approximately equivalent calorie value, the need for reducing or for increasing weight being met mainly by smaller helpings of the carbohydrate components for those overweight or by second helpings of these foods to the underweight.

Sometimes menus have required adaption to suit the taste of a particular individual, but with experience it has been found possible to do this without disturbing either the percentages of calories derived from fats, carbohydrates and protein, or the total calorie content of the diet. However, most of the personnel dealt with so far have had no marked idiosyncrasies and have been eager to eat practically any attractively prepared meal as long as it was not too outlandish and bizarre.

\section{DIET WHILE TRAINING}

The training diet provides approximately four thousand five hundred calories per day which corresponds fairly closely to the free choice intake discovered in young athletes at north Texas State College (24). Twenty five per cent of the calories are derived from fats, forty-five from carbohydrates and thirty per cent from protein. The traditionally high 
protein content of the diet is approved by many authorities $(11,30,31,36)$ though others deny its advantage $(7,10)$. It is based on the age old assumption that meat confers the strength of the animal eaten).

Presumably two thousand three hundred years ago Greek athletes must have found some factual basis for the supposition, or there would not have been the sharp swing in training diet from largely vegetarian to high meaty protein (13) which has influenced ideas on training ever since.

The diet contains a broad spectrum of essential amino-acids from animal and vegetable sources, and a high proportion of its fatty-acids are unsaturated, in keeping with present day thought on the production of athero-sclerosis (27). In the athlete, however, too much attention need not be paid to such considerations, especially if the substitution of margarine for butter gives the trainee the impression that he is not having the best possible diet, possibly on grounds of economy. He has to feel that he is living off the fat of the land. As Sir Adolphe Abrahams (1) put it: "We eat not only to satisfy hunger but to gratify the palate and for other reasons, not excluding that of passing the time. Consideration must be paid to the athlete in training, excluded from many of life's amenities, and some generosity of dietetic provision is justified on a psychological basis".

Four hours a day are devoted to meals, starting with breakfast, after an hour's work. Mealtimes provide a period of relaxation. No shop talk is allowed and certainly no post-mortems on deficient form. Pains are taken not to allow an individual to acquire the reputation of a big eater, since this proclivity may well become his trade-mark within the group and from then on, whether he wants to or not his position in the society will force him to eat more than anyone else. Items not liked are returned to the kitchen and are not allowed to be piled on to the plate of the trainee who has assumed the function of a dustbin. An enforced excess, eaten in this way to maintain an image, is a handicap to the individual concerned.

Breakfast takes an hour and consists of muesli with added Bemax, milk and sugar, (soft brown sugar is used as having some advantage over the more refined forms as a recent letter in the Lancet confirms (21) (although one of Professor Yudkin's staff from the Department of Nutrition at Queen Elizabeth College thought it mere food faddism (5); then follows eggs, poached, boiled, or scrambled, with grilled bacon or sausages, kidneys or fish, or cold ham. Tea or coffee with milk is drunk during the meal and toast or wholemeal bread, with butter and marmalade or other preserve, rounds off the meal. 
At the mid morning break a milk drink, hot or cold, is taken, reinforced with 30 grammes of skimmed milk powder per pint $(570 \mathrm{ml})$ and with an added carbohydrate preparation such as Bournvita, Horlicks, or drinking chocolate, or 60 grammes of Complan are added to a pint $(570 \mathrm{ml})$ of milk and flavoured with instant coffee. Biscuits (and preferably chocolate biscuits) are taken with this dirink. Half an hour is allowed.

Luncheon starts with a soup. A small quantity only is served so as to leave the appetite wetted for the entree, which is usually steak or beef, though other types of animal protein are used for variety. Potatoes, served in any manner except fried; salad or other raw vegetables with nuts, sultanas, raisins, orange, lemon, pineapple and cheese, and olive oil or mayonnaise dressings, complete the main course. The dessert consists of a fruit salad to which has been added glucose, sugar or honey, with custard, yoghourt or demi-sel cheese. Dried fruits (dates, figs, apricots and prunes) are chopped and added. The constituents of the fruit salad vary but it always contains some fresh fruits. When the entree course is considered low in calories ice cream is served in addition topped with a sauce made from an orange flavoured vitamin syrup (Vitavel). This meal, like breakfast, is a leisurely one and takes an hour. Water is taken in moderation before lunch and coffee or tea with milk after it.

In mid-afternoon a half hour's break is made when a milky drink, similar to that of the mid morning break, is served with biscuits. Fresh fruit is provided at this time.

The evening meal is the largest of the day and is similar in plan to the luncheon, the portions generally being heavier. An animal protein entree is followed by a dessert with high carbohydrate content and the meal ends with wholewheat bread, butter and cheese. Water is drunk before the meal and in moderation during the meal if desired, and tea or coffee is served after it. The food is attractively served and well-cooked, so as to preserve as much as possible of its vitamin and mineral content, which are well up to normal requirements. The vitamins of the $B$ group are also present in the Bemax, a stabilised wheat product, taken at breakfast time, the quantity provided containing $0.45 \mathrm{mg} \mathrm{Bl}, 0.2 \mathrm{mg} \mathrm{B}, 1.7 \mathrm{mg}$ nicotinic acid, $0.45 \mathrm{mg} \mathrm{B} 6$ and in addition $8.0 \mathrm{mg}$ vitamin $\mathrm{E}$ with useful quantities of protein, carbohydrate and trace elements. In Complan taken at least once a day, mid-morning or mid-afternoon, the vitamin content is as follows: $0.6 \mathrm{mg} \mathrm{Bl}, 0.6 \mathrm{mg} \mathrm{B2}, 4.4 \mathrm{mg}$ nicotinic acid, $0.2 \mathrm{mg} \mathrm{B} 6$; it also contains appreciable quantities of vitamins $A$ and $D$ and $4 \mathrm{mg}$ of vitamin $\mathrm{E}$, besides a useful mineral content (iron $4.4 \mathrm{mg}$ ). It is a high protein food, with fat and carbohydrate, and in the quantity taken provides 250 calories. In addition Wheat Germ Oil capsules are taken, providing 
$500 \mathrm{mg}$ of vitamin $\mathrm{E}$ daily and a ferrous iron preparation adding 500 $\mathrm{mg}$ of iron to the diet with copper and further quantities of the B group of vitamins derived from brewers yeast.

The vitamin and mineral supplementation is obviously a matter for controversy, some experts, notably Macintyre and Cureton, $(3,4,8,9$, $12,22,30,33,35)$ finding them effective while others $(18,19,20,25,27,31)$ deny their advisability. In the present instance though objective evidence has been difficult to find, the trainees have been working harder and have felt better since the supplementation started.

There are no other additives to the training diet. Sodium chloride is taken only in moderation as, not without good reason, it is considered that climatic conditions in Britain do not normally require salt supplementation. Anabolic steroids have been used in one instance to hasten muscle development in one who was under-developed. The effect was considered good and they would be used again if necessity arose.

TOURNAMENT DIET

In contrast to the high protein diet taken during training, on days when the students compete in tournaments a high carbohydrate diet is taken and heavy vitamin $\mathrm{B}$ and $\mathrm{C}$ supplementation is provided.

Two hours before the game muesli in the usual quantity is given, the one hundred and twenty gram portion contains three hundred and ninety calories not counting added milk and sugar, and 250 calories from Complan and 104 from Bemax. If desired a boiled egg, or a little bacon, with toast and marmalade, coffee or tea with milk may be taken in moderation. Two hours has proved an ample interval for the digestion of most of such a meal (28) before psychic inhibition produced by the nervous tension of the game paralyses the gut (23). One gramme of ascorbic acid and four tablets of Orovite (a high potency B complex preparation) are taken before the meal. This supplementation is special to the tournament days and is presented with the heaviest possible suggestions as to its magical powers, but there seems some reason to suppose that vitamin $C$ is necessary for adequate supra-renal activity (2), and that the B group increase powers of concentration and are involved in tissue oxidation and energy release $(4,29)$.

Like so much work in this field, mine can present only impressions, but these impressions are convincing enough to armour me against the scathing comments of those who have experimented with athletic dietetics in the laboratory $(6,7,10,15,16,34$,$) . No claims to originality$ are made for the diet. It is just wholesome food, with one or two novel touches which appeal to the palate of the trainee and make him feel that he 
is being specially cared for with the one aim of allowing him to give of his best when the great day comes.

\section{References}

1. ABRAHAMS A. Nutrition and athletics. Practitioner, 187:182, 1961.

2. BACCHUS H. and TOOMPAS.C.A. Science, 112:269, 1951.

3. BAKER A.Z. and MACINTYRE A.W. Feeding as a factor in training for sport and athletics. Health Educ. J. Sept. 1965.

4. BOURNE G.H. Vitamins and muscular exercise. Brit. J. Nut. ii: $261,1948 / 9$.

5. BROWN A.M. Personal communication. 1964.

6. BULlen M. B. MAYER J., and STARE F.J. Athletics and Nutrition. Am. J. Surg. 98: 344, 1959.

7. CHITTENDEN R.H. Physiological Economy in Nutrition. New York, 1904. Frederick A. Stokes Co.

8. CURETON T.K. Effect of wheat germ oil and vitamin E on normal human subjects in physical training programmes. Am. J. Physiol, 179: 628, 1954 .

9. CURETON T.K. Observations at the Melbourne Olympics: Swimming and diving. American Assoc. for Health etc. Convention, Detroit, Mar. 1957.

10. DARLING R.C., JOHNSON R.E., PITTS G.C., CONSOLAZIO, F.C. , and ROBINSON P.F. Effects of variations in dietary protein on the physical well-being of men doing manual work. J. Nutrition. 28: 273,1944 .

11. DAVIDSON S, MEIKLEJOHN A. P. and PASSMORE P. Human Nutrition and Dietetics p. 86 . London 1959. Livingstone.

12. FRANKAU I. M. Acceleration of co-ordinated muscular effort by nicotinamide. Brit. Med. J. ii: 601, 1943.

13. GARDINER E.N. Great Athletic Sports and Festivals, pp. 1-7. London, 1910. Macmillan Co. 
14. HAGGARD, H. W. and GREENBERG L.A. Diet and Physical Efficiency. New Haven, 1953. Yale University Press.

15. HALDI J., BACHMANN G., ENSOR C., and WYNN W. Muscular efficiency in relation to the taking of food and to the height of the respiratory quotient immediately before exercise. Am. J. Physiol, 121: 123,1938 .

16. HALDI J. and WYNN W. Work performance, respiratory exchange and certain blood constituents after 180 calorie meals of low and high carbohydrate content. J. Nutrition, 33: 287, 1947.

17. HUTCHINSON R.C. Meal Habits and their effects upon performance. Nutrition Abst. and Rev., 22: 283, 1952.

18 KEYS A. and HENSCHEL A.F. Vitamin supplementation of the U.S. Army rations in relation to fatigue and the ability to do muscular work. J. Nutrition, 23: 259, 1942.

19. KEYS A. et al: The performance of normal young men on controlled thiamine intakes. J. Nut: 26, 399, 1943.

20. KEYS A. et al: Physiological and biochemical function in normal young men on a diet restricted in riboflavin. J. Nut: 27: 165, 1944 .

21. LANCET ii: 760, 1964.

22. MACINTYRE A.W. Personal communication Dec. 1965.

23. MAYER $J$ and BULLEN B. Nutrition and athletic performance. Physiol Rev. 40: 391, 1960.

24. MAYS, R. W. and SCOULAR F. I. Food eaten by Athletes. J. Amer. diet Ass. 39: 225-227, 1961.

25. MONTOYE H.J. et al: Effects of Vitamin B 12 supplementation on physical fitness and growth of young boys. J. Appl. Physio., 7: 589,1955 .

26. PARNELL R.W. Behaviour and Physique: Arnold, London, 1958.

27. PORTMAN O.W. and STARE F.J. Dietary regulation of serum cholesterol levels. Physiol. Rev. 39: 407, 1959.

28. ROSE K. D. SCHNEIDER P. J. and SULLIVAN G. F. A liquid programme meal for athletes. J.A. M. A., 187: 130. 1961. 
29. SIMONSON E., ENZER N., BAER A. and BRAUN R. The influence of vitamin $B$ (complex) surplus on the capacity for muscular and mental work. J. Indust. Hyg., 24: 83, 1942.

30. TERUOKA G. and SAITO K. The protein demand in workers. Chem. Abstr , 51,18172, 1957.

31. THOMAS P. Effects of vitamin E on some aspects of athletic efficiency. Thesis, Los Angeles Univ. Southern Calif. 1957.

32. TUTTLE W.W. DAUM K. MYERS L. and MARTIN C. Effects of omitting breakfast on Physiologic response of men. J. Am. Diete A 26: 232, 1950.

33. VAN ITALLIE T.B. et al., Science and Med. of Exercise and Sport, Ch. 15, 296, 1962.

34. VYTCHIKOVA M.A. Increasing the Vitamin B 1 content in the rations of athletes. Chem. Abstr., 52:14787, 1958.

35. WARSZANA L. N. Sportarzliche Praxis, Sept., 118, 1960.

36. YAMAJI R. Studies on protein metabolism during muscular exercise. Pts. 1 and 11. J. Physiol. Soc. Japan, 13: 476 and $483,1951$. 